\title{
Teologia da Libertação: 50 anos de uma experiência pé no chão!
}

\section{Liberation Theology: 50 years of a downtown experience!}

\author{
Emerson Sbardelotti* \\ PUC-SP
}

Recebido em: 24/02/2021. Aceito em: 25/06/2021.

Resumo: A Teologia da Libertação é antes de tudo, uma libertação da Teologia. Ela quer ser uma Teologia para a nossa situação e não simples cópia da Teologia de outros países. Sua marca nestes 50 anos de experiência pé no chão é a opção pelos pobres e a espiritualidade libertadora, contra toda a pobreza, a favor da vida e da liberdade. O que move a Teologia da Libertação é o seguimento à Jesus de Nazaré, sua pedagogia, sua prática e sua espiritualidade libertadora. O objetivo do artigo é apresentar às novas gerações a Teologia da Libertação a partir de alguns elementos importantes de sua elaboração. A metodologia utilizada foi pesquisar bibliografia sobre a temática. Concluo, que nossa atenção, nosso olhar, a partir da Teologia da Libertação, se volta para o diálogo, o respeito e o encontro com novas realidades e saberes.

Palavras-chave: Teologia da Libertação. Opção pelos pobres. Espiritualidade libertadora.

\begin{abstract}
Liberation Theology is above all a liberation from Theology. It wants to be a theology for our situation and not a simple copy of theology of other countries. His mark in these 50 years of down-to-earth experience is the option for the poor and the liberating spirituality, against all poverty, in favor of life and freedom. What moves Liberation Theology is following Jesus of Nazareth, its pedagogy, its practice and its liberating spirituality. The objective of the article is to introduce the new generations to Liberation Theology from some important elements of its elaboration. The methodology used was to search bibliography on
\end{abstract}

* Doutorando em Teologia (Pontifícia Universidade Católica de São Paulo - PUC-SP, São Paulo, SP). Mestre em Teologia (Pontifícia Universidade Católica de São Paulo - PUC-SP, São Paulo, SP, 2016). Graduado em Teologia (Instituto de Filosofia e Teologia da Arquidiocese de Vitória do ES, IFTAV, Vitória, ES, 2012). Licenciado em História pelo Centro Universitário São Camilo - CUSC, Vitória, ES, 2010). Graduação em Turismo, Faculdade de Turismo de Guarapari, ES, FACTUR, 1996).

E-mail: sbardelottiemerson@gmail.com 
the subject. I conclude that our attention, our gaze, based on Liberation Theology, turns to dialogue, respect and the encounter with new realities and knowledge.

Keywords: Liberation Theology. Option for the poor. Liberating spirituality.

\section{Introdução}

A mensagem do Papa Francisco para o V Dia Mundial dos Pobres nos diz que:

"Jesus é o primeiro pobre, o mais pobre entre os pobres, porque os representa a todos. Os pobres são sacramento de Cristo, representam a sua pessoa e apontam para Ele. Jesus não só está do lado dos pobres, mas também partilha com eles a mesma sorte. Isto constitui também um forte ensinamento para os seus discípulos de todos os tempos". ${ }^{1}$

A partir desta afirmação do Papa Francisco, entende-se, que mais do que nunca, num contexto de pandemia, onde a cada dia a COVID-19 se prolifera com novas cepas e aumentam o número de mortos no Brasil, nossas ações humanitárias devem sobrepor a economia da morte presente no momento atual da história da sociedade brasileira; por isso, revistar a Teologia da Libertação, na comemoração de seus 50 anos de existência, é útil e necessário, para se vislumbrar um horizonte mais fraterno e justo, onde políticas públicas possam ser retomadas e ou ampliadas em torno do bem-estar social, do bem viver e do bem comum.

Na mesma mensagem, Francisco afirma que "a pobreza não é fruto do destino, é consequência do egoísmo". A Teologia da Libertação, desde o seu nascimento, se colocou no seguimento de Jesus na luta contra a pobreza em favor da justiça social. Jesus de Nazaré sempre foi e é o centro, a fonte de toda a Teologia da Libertação; mas o pobre de ontem, de hoje e de amanhã sempre será o locus theologicus da pesquisa no viés da libertação, dentro dos contextos históricos de cada época, o que não impede à TdL de identificar outros lugares de atuação.

Gustavo Gutiérrez explica em relação à Teologia da Libertação:

Como toda inteligência da fé, ela nasce em um lugar e em um momento precisos, buscando responder a situações históricas, móveis por natureza,

1 FRANCISCO. Mensagem do Papa Francisco para o V Dia Mundial dos Pobres. Disponível em: https://www.vaticannews.va/pt/papa/news/2021-06/mensagem-do-santo-padre-para-o-vdia-mundial-dos-pobres.html. Acesso em: 17 jun. 2021. 
que desafiam e, ao mesmo tempo, abrem novas rotas à tarefa evangelizadora da Igreja. A teologia é, por isso, permanente enquanto esforço de compreensão exigido pelo dom da fé e, simultaneamente, é mutável na medida em que responde a interpelações concretas e a determinado mundo cultural. ${ }^{2}$

Muitos artigos científicos, resenhas, livros, foram escritos desde que a Teologia da Libertação surgiu, por isso, o objetivo deste artigo é apresentar às novas gerações a Teologia da Libertação a partir de alguns elementos importantes de sua elaboração: o seguimento a Jesus de Nazaré, a espiritualidade da libertação e a opção pelos pobres. O intuito é que depois de cinco décadas, outros teólogos, outras teólogas da libertação surjam e façam a reflexão trilhar caminhos que até o momento ainda não foram trilhados ou que estão dando os seus primeiros passos.

E a grande missão de todo teólogo, de toda teóloga da libertação é a de animar e esperançar as pessoas, como nos pede Jesus de Nazaré, como insiste o Papa Francisco.

\section{Uma experiência pé no chão}

A Teologia da Libertação (TdL) completa em 2021, 50 anos de existência, a partir do lançamento do livro Teologia de la LiberaciónPerspectivas ${ }^{3}$, em Lima, no Peru, no ano de 1971, do dominicano Gustavo Gutiérrez, doutor em Teologia, possuidor de 23 títulos de Doutor Honoris Causa outorgados por universidades de diversos países.

Alguns meses antes da Conferência de Medellín (1968, Colômbia), Gustavo Gutiérrez havia promovido uma conferência com o título "Para uma Teologia da Libertação", dando nome à reflexão genuína e teológica desenvolvida na atmosfera pós-conciliar latino-americana e caribenha, que implantou os valores e as novidades conciliares nestas terras continentais. No mesmo ano, exilado nos Estados Unidos, Rubem Alves, doutorando-se em Teologia, escreve sua tese meditando sobre a possibilidade de libertação. Dando-lhe o título Towards a Theology of Liberation (Por uma Teologia da Libertação). Nome este que se encontra como o próprio autor sempre afirmou, no original e no registro de direitos

2 MÜLLER, Gerhard Ludwig; GUTIÉRREZ, Gustavo. Ao lado dos pobres: Teologia da Libertação. São Paulo: Paulinas, 2014. p. 115.

3 As citações feitas neste artigo são da tradução em português de GUTIÉRREZ, Gustavo. Teologia da Libertação - Perspectivas. São Paulo: Edições Loyola, 2000. 
autorais. Rubem Alves ${ }^{4}$ argumentará, em muitas entrevistas a respeito da TdL, que não sabia que aquele era um primeiro afluente, quase sem água e sem nome, de um grande rio: a Teologia da Libertação.

Em 1971, no Brasil, primeiro em forma de dez artigos publicados para a revista de espiritualidade Grande Sinal, e um ano depois em livro, era publicado Jesus Cristo Libertador ${ }^{5}$, do então frei franciscano Leonardo Boff, doutor em Filosofia e Teologia, detentor do Prêmio Right Livelihood (Correto Modo de Vida), conhecido como o Nobel alternativo, Estocolmo, Suécia, em 2001.

Para Leonardo Boff:

Em grande parte, a teologia da libertação se construiu ao redor do tema Jesus Cristo Libertador. Se não anunciarmos a Jesus como Libertador não anunciamos o Jesus que os Apóstolos conheceram e nos transmitiram. Sua prática, sua mensagem, sua morte como consequência de seu compromisso com o Pai e com os bens do Reino na história e, finalmente, sua ressurreição, inauguração da libertação em plenitude, fundaram uma mistica poderosa de solidariedade e até de identificação com os pobres contra a sua pobreza. O seguimento de Jesus firmava o comportamento do cristão na sociedade a ser transformada. ${ }^{6}$

Em El Salvador, o mártir Ignacio Ellacuría publica um artigo intitulado: Liberación: misión y carisma de la iglesia latino-americana. No Uruguai, Hugo Assmann também publica o livro coletivo: Opresión-liberación: desafio de los cristianos.

50 anos de uma experiência frutífera, cercada de perseguições, difamações e inverdades, na maioria das vezes causadas dentro da própria Igreja que não se esforçou em entender o processo histórico, político e social da América Latina e Caribe onde essa Teologia germinou; tentaram de muitas formas, mas não conseguiram desqualificá-la do objetivo único de sua existência que é a defesa constante da vida!

4 Cf. ALVES, Rubem. Teologia da Libertação, Igreja Presbiteriana e Ditadura Militar. Disponível em: https://www.youtube.com/watch?v=njJW1xAMW3Y. Acesso em: 3 jun. 2021.

5 As citações feitas neste artigo são da obra: BOFF, Leonardo. Jesus Cristo Libertador. Petrópolis: Editora Vozes, 2009.

6 BOFF, Leonardo. Jesus Cristo Libertador. 20. ed. Petrópolis: Editora Vozes, 2009. p. 13-14. 
Era o início de uma longa travessia. Travessia que ainda continua. As sementes foram jogadas e caíram em terra boa e estão dando frutos.

\subsection{Fases}

Resumidamente apresento fases do itinerário feito pela TdL até os dias atuais, antes de apontar alguns elementos, que em minha humilde opinião continuam hodiernos e, por isso, incomodam.

Na primeira fase da TdL-década de 1960, temos a gestação e o nascimento desta teologia genuinamente latino-americana e caribenha; herdeira das intuições do Concílio Vaticano II, do primeiro Pacto das Catacumbas da Igreja Servidora e Pobre, da Conferência de Medellín, em seu capítulo sobre a Pobreza da Igreja; nesta Conferência, refletiu-se pela primeira vez a palavra Libertação. Medellín efetiva a opção radical e evangélica pelos pobres. Medellín é o retrato de uma Igreja de pastores-profetas, que não se calavam, mesmo sabendo dos riscos em plena ditadura militar.

Na segunda fase da TdL - década de 1970, a opção pelos pobres faz com que a Igreja denuncie a situação econômica, política e social de extrema pobreza. As Comunidades Eclesiais de Base (CEBs), mais de 100 mil na época, aparecem como o locus theologicus do viver e do pensar a TdL. Nas CEBs reconhecem nos pobres, nos excluídos, nos oprimidos as feições sofredoras de Jesus de Nazaré, que se faz nosso amigo, nosso irmão. Aquele que nos dá esperança na luta cotidiana em defesa da Vida. Neste período aconteceu a Conferência de Puebla.

Na terceira fase da TdL - década de 1980, ainda não se usava o plural: Teologias da Libertação, porém, a grande preocupação era com as minorias discriminadas: os jovens, as mulheres, os negros, os indígenas, entre tantas outras que iam surgindo. É neste período que teólogos e teólogas da libertação, como a própria TdL é muito perseguida por setores da hierarquia romana. São desta década os dois documentos da Congregação para a Doutrina da Fé (ex - Santa Inquisição; ex-Santo Ofício) sobre a TdL.

Na quarta fase da TdL - década de 1990, Leonardo Boff, atento aos sinais dos tempos, inicia a primeira grande refundação da TdL ao experimentá-la a partir do viés ecológico: não é só o pobre que grita, mas, a Terra grita! Se não cuidarmos da Terra, não haverá uma outra Arca de Noé, todas, todos nós morreremos. Nesta década busca-se redefinir 
a TdL, retornando às fontes, aos elementos constitutivos. Neste período aconteceu a Conferência de Santo Domingo, onde o Método Ver-Julgar- Agir foi colocado para escanteio.

Na quinta fase da TdL-década de 2000 até os dias atuais, temos a refundação da TdL em saída para as periferias. Num momento político e economicamente propício, outras abordagens desta Teologia aparecem no horizonte recebendo o nome, agora, no plural, de Teologias da Libertação (cito apenas algumas: jovens, negros, indígenas, mulheres, de outra condição sexual, da ecologia, do ecumenismo, pluralista). São estas abordagens que fizeram reflorescer a TdL, que mantêm acesa a chama da esperança, da utopia e da poesia.

Neste período as perseguições e difamações continuaram contra a TdL e contra seus teólogos e teólogas; aconteceu a Conferência de Aparecida, onde a opção pelos pobres foi retomada por Bento XVI no pronunciamento de abertura; contudo, no papado de Francisco, uma nova primavera abraçou a Igreja, seus escritos e os sínodos que convoca, são verdadeiras lufadas de vento, que levam para longe a poeira dos anos passados; afinal, Francisco está fazendo uma nova recepção do Concílio Ecumênico Vaticano II, e tem nos convidado a participar desta recepção.

A TdL não tem receitas prontas, mas sabe onde quer chegar, dando um passo depois do outro, nos pequenos grupos, escutando, estando em sinodalidade. É uma Teologia orientada para a defesa da Vida, desenvolvida através de laços de fraternidade, igualdade, liberdade. Desenvolvida a partir dos povos crucificados, com a missão de fazer descer da cruz os/as crucificados/as. Portanto, uma teologia a partir das vítimas, uma teologia a partir dos mártires, uma teologia desde o mais profundo da nossa História hodierna.

O importante não é a TdL mas a libertação dos pobres! A TdLé uma teologia do Reino de Deus. Teologia que se orienta pelo que fazia e falava Jesus de Nazaré que colocou o Reino de Deus no centro da discussão.

\subsection{Dimensões radicais}

Duas dimensões radicais orientam a TdL: 1. Opção pelos pobres; 2. Seguimento de Jesus de Nazaré! A TdL não tem sua fonte no Marxismo, mas, tem sua fonte na Bíblia: partindo do Êxodo, passando pelos profetas, tendo seu auge em Jesus de Nazaré e seguindo pelas primeiras comunidades até germinar e se esparramar em Nossa América a partir 
da Conferência de Medellín que colocou em prática as inspirações proféticas do Concílio Ecumênico Vaticano II. É no seguimento a Jesus de Nazaré que está o fundamento da TdL; é na opção pelos pobres de Jesus de Nazaré que está a opção pelos pobres da TdL.

Gerhard Ludwig Müller argumenta:

Uma fonte totalmente significativa é, para a Teologia da Libertação, a Constituição pastoral do Vaticano II Gaudium et spes, sobre a Igreja no mundo contemporâneo. Já na Lumen gentium o Concílio apresentara a Igreja não como uma comunidade religiosa separada do mundo e autossuficiente, mas como sacramento de salvação para o mundo. A Igreja, atuando como sinal e instrumento de união de Deus com os homens e dos homens entre eles, é serva da salvação que Deus constituiu historicamente, de uma vez por todas e definitivamente, em Jesus Cristo; essa salvação, que, através do Espirito Santo, ele colocou como perene princípio da história humana e da edificação de uma sociedade digna do homem. ${ }^{7}$

É a TdL um dos motores desta Igreja em saída, proposta pelo Papa Francisco, pois a TdL sempre está em saída, pois, nestes anos todos de sua existência, sempre pregou uma mensagem samaritana, de cuidado, de solidariedade e de esperança.

A intuição de Gustavo Gutiérrez continua atual neste momento sombrio da história brasileira:

A "nova época histórica" de que fala Medellín continua sendo o contexto vital da América Latina. Trata-se, em termos bíblicos, de um kairós, um tempo propício e exigente de interpelação do Senhor, no qual somos chamados a dar um testemunho muito preciso. Nesse kairós, os cristãos estão experimentando um momento tenso e intenso de solidariedade, de reflexão e de martírio. Esse marco estimulante e imediato nos permite retomar e aprofundar o que há tempos consideramos os três pontos fundamentais dessa linha teológica: o ponto de vista do pobre, o quefazer teológico e o anúncio do Reino de vida. ${ }^{8}$

Não existe Teologia da Libertação sem ter um pé na realidade de miséria e da pobreza que tem assolado a nação brasileira, em especial,

7 MÜLLER, Gerhard Ludwig. Pobre para os pobres: a missão da Igreja. São Paulo: Paulinas, 2014. p. 35.

8 GUTIÉRREZ, Gustavo. Teologia da Libertação: Perspectivas. São Paulo: Edições Loyola, 2000. p. 15. 
como também outros países latino-americanos; e sem ter um pé na reflexão teológica e pastoral. Junto ao povo de Deus, a TdL fornece ferramentas para construir uma sociedade mais justa e mais fraterna.

Há um adoecimento eclesial preocupante. Os lúcidos são considerados hereges. Infelizmente, a imbecilização que se percebe na sociedade brasileira também está presente em algumas lideranças nas paróquias e dioceses. Não se trata de voltar ao que era, porque o que era, já estava ruim, antes da pandemia, e agora ficou muito pior. Só a certeza de que não voltaremos ao normal de antes, já é um sinal dos tempos e de esperança. Pessoas que eram boas, nesta pandemia, melhoraram. Pessoas que eram ruins, estão perdendo o que havia nelas: o resto de humanidade. Nos dias atuais, a fé e a política estão cada vez mais juntas, porém, não estão sendo usadas em favor do povo, há uma distorção cada vez maior desta relação com resultados catastróficos. É terrível ter que constatar que o clericalismo e o negacionismo crescem a passos largos, mesmo com todos os alertas emitidos pelo Papa Francisco; infelizmente, não encontro outras palavras e constato que são cânceres se espalhando em nossa Igreja, e matam. O cheiro da morte está cada vez mais perto:

Contudo, a Teologia da Libertação não morrerá enquanto houver homens que se deixem contagiar pelo agir libertador de Deus e que façam da solidariedade com os sofredores, cuja vida é espezinhada, a medida da sua fé e a mola do seu agir na sociedade. Teologia da Libertação significa, em suma, crer em Deus como Deus da vida e como fiador de uma salvação entendida na sua inteireza, a qual resiste a deuses e ídolos responsáveis por mortes prematuras, pobreza e degradação do homem. ${ }^{9}$

A sociedade em que vivemos é uma sociedade plural. Sendo plural está cercada de desafios, de perspectivas, que se abrem e se oferecem a todas as pessoas, todos os dias, esperando de nós apenas uma atitude de diálogo. Uma Igreja que não dialoga com a realidade urbana está fadada a desaparecer. Uma Igreja que não dialoga com o diferente está fadada a se fechar em si mesma e a desaparecer.

No auge das controvérsias contra a Teologia da Libertação, uma palavra de diálogo, de encontro e de respeito, encheu de esperança todas aquelas pessoas que experimentavam no cotidiano das Comunidades Eclesiais de Base a Teologia da Libertação. Relembro as palavras de São João Paulo II que em 9 de abril de 1986 dizia aos bispos do Brasil:

9 MÜLLER, 2014, p. 34. 
Na medida em que se empenha por encontrar aquelas respostas justas penetradas de compreensão para com a rica experiência da Igreja neste País, tão eficazes e consonantes e coerentes com os ensinamentos do Evangelho, da Tradição viva e do perene Magistério da Igreja - estamos convencidos, nós e os Senhores, de que a Teologia da Libertação é não só oportuna, mas útil e necessária. Ela deve constituir uma nova etapa - em estreita conexão com as anteriores - daquela reflexão teológica iniciada com a tradição apostólica e continuada com os grandes padres e doutores, com o magistério ordinário e extraordinário e, na época mais recente, com o rico patrimônio da Doutrina Social da Igreja, expressa em documentos que vão da Rerum novarum à Labores exercens. ${ }^{10}$

\subsection{Desafios atuais}

E como tem sido oportuna, útil e necessária a Teologia da Libertação, tendo em vista os diferentes encontros teológicos e congressos que foram realizados sobre a TdL, desde os anos de 1970 até os dias atuais, cito alguns: 1. Escorial (Madri), 1972; 2. Escorial (Madri), 1992; 3. Congresso Continental de Teologia - São Leopoldo (UNISINOS), 2012; 4. Encontro Nacional de Juventudes e Espiritualidade Libertadora (ADITAL) - ENJEL - Fortaleza, 2014; 5. II Congresso Continental de Teologia - Belo Horizonte, 2015; 6. II Encontro Nacional de Juventudes e Espiritualidade Libertadora - II ENJEL, Poá-SP, 2017; 7. III Congresso Continental de Teologia - El Salvador, 2018. 8. Os Intereclesiais das CEBs desde 1975 até o próximo em 2023. 9. Os encontros da Associação Ecumênica dos Teólogos do Terceiro Mundo (ASETT). 10. Antes de cada Fórum Social Mundial, dois dias antes, acontece o Encontro Internacional da Teologia da Libertação, com mais ou menos 3 mil participantes, sempre renovando os desafios da Teologia da Libertação.

Nestes encontros a TdL viralizou e se planetarizou, tornando-se a parte mais criativa do Cristianismo. Estes são alguns encontros e congressos que fizeram e seguindo a tradição, fazem uma Teologia da Libertação com qualidade e novidade. Libertação se opõe à opressão!

Victor Codina ${ }^{11}$ aponta dez desafios atuais da TdL: 1. Não idolatrar a TdL; 2. Necessidade de reafirmar o essencial; 3. Da Teologia da Libertação

10 JOÃO PAULO II. Mensagem do Santo Padre ao Episcopado do Brasil - Roma, 9 de abril de 1986. São Paulo: Edições Loyola, 1986. p. 6.

11 Cf. CODINA, Victor. Nuevos desafios de la Teología de la Liberación. Perspectiva Teológica, Belo Horizonte, v. 48, n. 2, maio/ago. 2016, p. 229-243. 
às Teologias da Libertação; 4. De uma teologia patriarcal a uma teologia feminina; 5. Da opção pelos pobres a opção pela Terra; 6. De uma TdL, todavia muito ocidental a uma TdL mais autóctone; 7. De uma teologia cristocêntrica a uma teologia mais pneumática; 8 . De uma teologia muito acadêmica a uma teologia mais iniciática; 9. De uma teologia de "dinossauros" a uma teologia de novas gerações; 10. Mysterium misericordiae.

Marcelo Barros ${ }^{12}$ lembra-nos outros desafios atuais da TdL: 1. Teologia da Libertação: libertação da Teologia; 2. O desafio da Teologia da Libertação e os novos pentecostalismos; 3 . Novas teologias da libertação nessa era de globalização - com três vertentes: 3.1. O desafio da economia neoliberal; 3.2. O desafio da política; 3.3. Os meios de comunicação e as guerras híbridas; 4 . Teologia da Libertação e os processos latino-americanos; 5. O desafio do pluralismo; 6. O desafio do risco nuclear; 7. O desafio do paradigma ecológico; 8. O desafio do especifismo e o cuidado com os animais; 9. Teologias da Libertação e o paradigma do bem-viver; 10. Teologias da Libertação e o desafio de uma aliança da humanidade pela Vida.

São desafios que se complementam e que nos fazem acordar para a atualidade de cenário de Igreja que, por vezes, se afasta da opção pelos pobres e do seguimento de Jesus de Nazaré; e contrapô-lo com o projeto de Igreja em saída que o Papa Francisco estimula em nós:

Naquele "ide" de Jesus, estão presentes os cenários e os desafios sempre novos da missão evangelizadora da Igreja, e todos somos chamados a esta nova "saída" missionária. Cada cristão e cada comunidade há de discernir qual é o caminho que o Senhor lhe pede, mas todos somos convidados a aceitar esta chamada: sair da própria comodidade e ter a coragem de alcançar todas as periferias que precisam da luz do Evangelho.

Saiamos, saiamos para oferecer a todos a vida de Jesus Cristo! Repito aqui, para toda a Igreja, aquilo que muitas vezes disse aos sacerdotes e aos leigos de Buenos Aires: prefiro uma Igreja acidentada, ferida e enlameada por ter saído pelas estradas, a uma Igreja enferma pelo fechamento e a comodidade de se agarrar às próprias seguranças. Não quero uma Igreja preocupada com ser o centro, e que acaba presa em um emaranhado de obsessões e procedimentos. ${ }^{13}$

12 Cf. BARROS, Marcelo. Teologias da Libertação para os nossos dias. Petrópolis: Editora Vozes, 2019. p. 285-316.

13 FRANCISCO. Exortação Apostólica Evangelii Gaudium - A Alegria do Evangelho: ao Episcopado, ao clero, às pessoas consagradas e aos fiéis leigos sobre o anúncio do Evangelho no mundo atual. São Paulo: Paulinas, 2013. p. 19-20, 42-43. 
E se passaram 50 anos desde que a Teologia da Libertação no seguimento de Jesus de Nazaré aproximou os povos latino-americanos de sua Palavra, de sua face. Por conta desta aproximação aprendemos que hoje em dia não se deve falar de TdL no singular, mas no plural, pois existem várias Teologias da Libertação. Porém, há muitas pessoas que ainda não foram apresentadas à Teologia da Libertação, e o importante na caminhada da libertação é o processo de educação da fé, onde as fontes são apreciadas, e as bases de todo o conhecimento já vivido pode ser mais uma vez experimentado, levando em consideração toda a sua história, para enfim, chegar nos resultados atuais. Graças à Teologia da Libertação os povos da América Latina e Caribe, sob o peso das ditaduras militares, puderam manter viva a esperança de um futuro melhor. Hoje, com o avanço de forças fundamentalistas e anacrônicas dentro da Igreja e da sociedade em geral, a TdL torna-se, mais uma vez, fundamental, na construção de pontes de diálogo, respeito e encontro.

Inicialmente era uma teologia dos teólogos formados na Europa, mas hoje a força da TdL está nas bases, pois conseguiram criar pensadores orgânicos, e estão levando avante a perspectiva da liberdade dos pobres e da Terra. Hoje é uma teologia popular, autônoma, e com o conceito de sinodalidade: "trabalhar juntos", todas as pessoas são convidadas a enriquecer com características novas a TdL e neste sentido, ela está bem viva, e está onde deve estar, nas realidades periféricas, que são as bases da sociedade.

Onde há pobreza e opressão, aumenta o desejo de libertação!

\section{Opção - Igreja dos Pobres}

A Igreja dos Pobres está aí, mais viva do que nunca, não mais tão falada como antigamente, pois foi duramente perseguida e difamada, mas continua presente em várias lideranças que não se cansam de lutar por um outro mundo novo e possível; por CEBs onde todos e todas se conheçam e celebrem a vida, a morte e a ressurreição de Jesus de Nazaré, e querem seguir os passos do Mestre, dentro de uma pedagogia e prática libertadora, assumindo todos os riscos que a caminhada irá oferecer. Todos, todas sabem muito bem que não há como fugir da cruz para obter a salvação. Não há luz, sem cruz! 
A Igreja dos Pobres interfere na totalidade da Igreja e de quem nela participa!

A Igreja quando é perseguida, é mais profética, mais cheia de vida! Quando se acomoda, quando está inerte, não cria problema algum para quem oprime e extermina!

Só quem vive na América Latina e Caribe saberá entender com maior clareza o processo que culminou na Teologia da Libertação, o que de fato é e o que representa a Teologia da Libertação em seus 50 anos de existência.

Se houvesse que resumir o conceito, a ideia central da Teologia da Libertação em uma só frase esta seria: Opção pelos pobres!

A Teologia da Libertação só tem sentido quando o eixo estruturador é a opção pelos pobres contra a pobreza e a favor da justiça social da libertação. Hoje não é uma teologia acadêmica, mas de viés popular.

Leonardo Boff explica:

$O$ punctum stantis et cadentes $d a T d L$ é o pobre concreto, suas opressões, a degradação de sua vida e os padecimentos sem conta que sofre. Sem o pobre e o oprimido não há TdL. Toda opressão clama por uma libertação, por isso, onde há opressão concreta e real que toca a pele e faz sofrer o corpo e o espírito aí tem sentido lutar pela libertação. Herdeiros de um oprimido e de um executado na cruz, Jesus, os cristãos encontram em sua fé mil razões por estarem do lado dos oprimidos e junto com eles buscar a libertação. Por isso a marca registrada da TdL é agora e enquanto se ouvir o clamor dos oprimidos: a opção pelos pobres contra sua pobreza e a favor de sua vida e da justiça social. ${ }^{14}$

O grito dos pobres ecoa por toda a Terra, e cada dia mais alto. Da mesma forma, a Terra grita diante do desenvolvimento insustentável: sustentar o desenvolvimento e crescimento econômico das nações poderosas em detrimento do planeta, a exploração indiscriminada dos recursos e, pior, a sustentabilidade da pobreza e da miséria dos países subdesenvolvidos, é levar o planeta que conhecemos ao caos irreversível.

A opção pelos pobres, nasce do desejo de Deus, se torna uma prática jesuânica, e é a herança da Igreja dos Pobres querida por São João XXIII, da Gaudium et Spes, do Pacto das Catacumbas, da Populorum

14 BOFF, Leonardo. Teologia da Libertação. In: DICIONÁRIO DO CONCÍLIO VATICANO II. São Paulo: Paulinas. Paulus, 2015. p. 930. 
Progressio, do método Ver-Julgar-Agir, na Leitura Popular da Bíblia e se firmou com a atualização do Concílio Ecumênico Vaticano II na Conferência de Medellín, expandindo suas fronteiras.

Francisco de Aquino Júnior explica:

Na medida que a Igreja é a comunidade dos seguidores e seguidoras de Jesus Cristo e na medida em que no centro da vida e missão de Jesus Cristo está o reinado de Deus, cuja característica mais central e decisiva é a garantia dos direitos dos pobres e marginalizados, a Igreja se constitui como "Igreja dos pobres", para usar a expressão do Papa João XXIII. O ser dos pobres aparece, aqui, com um aspecto "essencial e primordial" do "mistério de Cristo na Igreja" (Cardeal Lercado), como um dos "traços" essenciais da Igreja (Marie-Dominique Chenu), como "uma nota constitutiva e configurativa de toda a Igreja" (Ignacio Ellacuría), como dimensão "essencial da 'verdade' da Igreja" (Álvaro Barreiro). Trata-se, aqui, portanto, de uma questão dogmática, de uma verdade fundamental da revelação e da fé cristãs, de uma questão de ortopráxis e de ortodoxia teológica, sem a qual uma "Igreja" pode ser tudo, menos Igreja de Jesus Cristo. A Igreja que é e deve ser sempre mais una, santa, católica e apostólica (Concílio de Constantinopla em 381), é e deve ser sempre mais dos pobres (João XXIII). Essa nota é tão essencial e fundamental na Igreja quando as demais, e é tão antiga quanto elas, ainda que sua formulação em termos dogmáticos seja recente.

Certamente, o ser dos pobres não esgota a realidade da Igreja. Afinal, a Igreja que é dos pobres é também e sempre una, santa, católica e apostólica, para usar a formulação do símbolo Niceno-constantinopolitano. Mas essa é uma de suas notas constitutivas e essenciais. De modo que, sem ela, a Igreja deixa de ser Igreja de Jesus Cristo - seu corpo vivo e atuante na história.

“Justamente porque a 'opção preferencial pelos pobres' pertence ao coração mesmo do Evangelho de Jesus Cristo, quando um 'cristão' [ou uma comunidade] não assume conscientemente na sua vida, procurando vivê-la com maior fidelidade, e mais ainda quando de fato se opõe a ela, quaisquer que sejam as razões aduzidas, ele [ela] deixa ipso facto de ser cristão, pois coloca-se em contradição frontal com o Evangelho do Reino proclamado por Jesus e com a mesma pessoa de Jesus, que é, na expressão de Orígenes, a autobasileia, o Reino em pessoa". ${ }^{15}$

15 AQUINO JÚNIOR, Francisco de. Teologia em saída para as periferias. São Paulo: Paulinas; Recife: UNICAP, 2019. p. 176-177. 
Portanto, as passagens do Deus Libertador no Primeiro Testamento: no Êxodo, nos Profetas, no Salmo 82,2-4 ${ }^{16}$, onde Deus se faz presente na luta do povo em defesa da vida, não deixam margem para dúvida por uma opção pelos pobres. No Segundo Testamento, encontram-se as Palavras e as Ações de Jesus de Nazaré nos Evangelhos, juntamente com o testemunho das Primeiras Comunidades Cristãs e as cartas de amor e compromisso redigidas por pessoas que viveram até as últimas consequências a alegria do Evangelho. A Palavra de Deus é a fonte original e primordial da Teologia da Libertação.

\section{Espiritualidade da Libertação}

A opção pelos pobres é a prática da Espiritualidade da Libertação que brota de Jesus de Nazaré! Cada um, cada uma de nós, nasce com Espiritualidade, no cotidiano da vida, aprendemos a experimentar e a colocar em prática esta Espiritualidade. É Espiritualidade Libertadora pois nasce do desejo profundo de Jesus de Nazaré em libertar as pessoas de ontem e de hoje das correntes que impedem viver com plenitude e dignidade humana. É Espiritualidade Libertadora pois liberta a espiritualidade de antigos conceitos que não produzem frutos e atrapalham a caminhada. Antes de existir uma Teologia da Libertação, existia a Espiritualidade da Libertação. Portanto, não é exagero repetir: se praticamos uma Teologia da Libertação, mesmo com tantas dificuldades, antes experimentamos uma Espiritualidade da Libertação que é profética, samaritana, do cuidado, do respeito, do encontro, do diálogo, enfim, do seguimento à pedagogia e a prática de Jesus de Nazaré.

Gustavo Gutiérrez argumenta:

A espiritualidade, no sentido estrito e profundo do termo, é o domínio do Espirito. Se "a verdade nos fará livres" (Jo 8,32), o Espírito que "nos conduzirá à verdade completa" (Jo 16,3) nos levará à liberdade plena. À liberdade de tudo o que nos impede de realizar-nos como pessoa e filhos de Deus, e à liberdade para amar e entrar em comunhão com Deus e com os demais.

16 "Até quando julgareis injustamente favorecendo os culpados? Sede juízes para o fraco e o órfão, fazei justiça ao infeliz e ao indigente; libertai o fraco e o pobre, livrai-os da mão dos culpados". 
Uma espiritualidade é uma forma concreta, movida pelo Espírito, de viver o Evangelho. Uma maneira precisa de viver "diante do Senhor" em solidariedade com todos os seres humanos, "com o Senhor" e diante deles. Ela surge de uma experiência espiritual intensa, depois tematizada e testemunhada. Essa experiência, em função de um compromisso com o processo de libertação, começa a ser feita por alguns cristãos. As experiências de gerações anteriores lá estão para respaldá-la, mas também, sobretudo hoje, para fazê-la ver que deve percorrer um caminho inédito. Ao hoje da história e do Evangelho corresponde um presente da experiência espiritual que não pode ser escamoteado. Espiritualidade significa reordenação dos grandes eixos da vida cristã em função desse presente.

Uma espiritualidade da libertação estará centrada na conversão ao próximo, ao homem oprimido, à classe social espoliada, à raça desprezada, ao país dominado. Nossa conversão ao Senhor passa por esse movimento. A conversão evangélica é, de fato, a pedra de toque de toda espiritualidade. Conversão significa radical transformação de nós mesmos; significa pensar, sentir e viver como Cristo presente no ser humano despojado e alienado. Converter-se é comprometer-se com o processo de libertação dos pobres e explorados, comprometer-se lúcida, realística e concretamente. Não só com generosidade, mas também com análise de situação e com estratégia de ação. Converter-se é saber e experimentar que, contrariamente às leis do mundo da física, só se está de pé, segundo o Evangelho, quando nosso eixo de gravidade passa fora de nós. ${ }^{17}$

A 50 anos, a Teologia da Libertação espalhou raízes como uma reflexão espiritual. Antes da TdL veio a Espiritualidade da Libertação (EdL). Neste momento em que vivemos um tempo de isolamento social, fraternal e familiar, estas raízes da EdL e da TdL se aprofundam ainda mais nestas igrejas familiares, nos processos de educação da fé e da vida que apontarão para algo novo: nada mais será como o que vivemos antes.

Espiritualidade é tudo aquilo que dentro de mim, de nós, faz uma transformação. Tudo aquilo que me leva a mudar enquanto ser humano. A espiritualidade desce da cabeça para o coração e através do respeito, diálogo e encontro, coloca-me em direção ao diferente fazendo, portanto, uma mudança interior e exterior.

Marcelo Barros afirma:

17 GUTIÉRREZ, 2000, p. 260-261. 
Todas as pessoas comprometidas com a transformação do mundo, de um modo ou de outro, vivem elementos de uma espiritualidade humana e centrada na mística da vida. É importante reafirmar esse caráter simples, não elitista da espiritualidade cristã libertadora. Por essa abertura antropológica fundamental, em si mesma, ela já seria sociopolítica libertadora e pluralista, no sentido de abertura a outros caminhos espirituais. A Teologia da Libertação sempre nos ensinou que não há duas histórias e nos ajudou a superar os dualismos nos quais fomos formados. Do mesmo modo, não podemos pensar que a espiritualidade seja um caminho diferente ou além da caminhada que fazemos cotidianamente para nos converter interiormente e para transformar o mundo. ${ }^{18}$

A espiritualidade da libertação é a espiritualidade que vivo e partilho, pois, está na herança, na pedagogia, na prática e no seguimento de Jesus de Nazaré. A espiritualidade é para mim alteridade, pois, me coloco sempre na estrada que me leva ao outro, me leva ao diferente. Não é fácil esta caminhada, se não conseguimos respeitar o outro, não conseguimos dialogar com o outro, não conseguimos encontrar o outro.

A espiritualidade é para mim o encontro do ser humano com o Deus da Vida, pois, só há espiritualidade dentro de um cenário em que está inteiramente inserida na realidade histórica. É fácil falar do fim, porém, o difícil é indicar o começo e o caminho.

As CEBs são o locus theologicus do viver a Espiritualidade da Libertação e do pensar a Teologia da Libertação. Elas constituem um dos traços mais dinâmicos da vida em comunhão, da vida em sociedade. O método para ligar a relação fé e vida é o Ver-Julgar-Agir, acrescido atualmente do Rever-Celebrar-Sonhar; que é vivido e discutido em pequenos grupos, nas equipes de serviço.

A Conferência Nacional dos Bispos do Brasil (CNBB), pronunciando-se sobre as CEBs afirma:

Fator de renovação interna e novo modo de a Igreja estar presente no mundo, elas constituem, por certo, um fenômeno irreversivel, senão nos detalhes de sua estruturação, ao menos no espírito que as anima. [...]. As CEBs não surgiram como produto de geração espontânea, nem como fruto de mera decisão pastoral. Elas são resultado da convergência de descobertas e conversões pastorais que implicam toda a Igreja - povo de Deus, pastores e fiéis - na qual o Espirito opera sem cessar. [...]. De

18 BARROS, 2019, p. 212. 
forma privilegiada, as CEBs redescobrem, na leitura bíblica, o aspecto libertador da História da Salvação. Veem sua própria caminhada prefigurada no Exxodo do povo de Israel e atualizada na vivência do Mistério Pascal de Jesus Cristo. Assumem sua luta pela justiça como realização do profetismo na sociedade de hoje. Redescobrem também a vivência fraterna das comunidades primitivas que se encontravam na oração e na fração do pão, partilhavam seus bens e viviam unidos num só coração e numa só alma. ${ }^{19}$

Viver pelo e no Espírito numa Comunidade Eclesial de Base é confirmar que onde um, dois ou três estiverem reunidos em nome de Jesus de Nazaré, ele sempre estará no meio deles. As CEBs são o lugar da manutenção da esperança, dos sonhos, da profecia!

Pedro Casaldáliga afirma:

A Espiritualidade da Libertação só pretende ser espiritualidade cristã $e$, nesse sentido, a espiritualidade cristã de sempre. $O$ "seguimento" de Jesus, viver segundo seu Espírito, praticar sua prática: "A prática de Jesus". Com os traços especificos do lugar e do tempo, cultura e história, desafios e esperanças, que aqui vivemos como povo e como Igreja. [...]. Ser pobre com os pobres. Partilhar. Ser livre e libertar. Contemplar o Deus Vivo na vida e na morte de seus filhos. Viver Belém e a Páscoa. ${ }^{20}$

Reafirmo: sem os pobres não existiria a Teologia da Libertação. O centro da Teologia da Libertação é Jesus de Nazaré. Jesus optou pelos pobres. Por isso, quem segue a Jesus, opta pelos pobres. Não porque os pobres são melhores, mas porque são as vítimas! Por conta desta opção, Jesus foi perseguido e assassinado! A Teologia da Libertação fez a mesma opção. E por isso paga um preço muito caro. E por isso, quem se coloca à disposição do Reino da Vida também tem a mesma sina.

Na Instrução sobre a Liberdade Cristã e a Libertação encontra-se:

Sob suas múltiplas formas - extrema privação material, opressão injusta, enfermidades físicas e psíquicas e, por fim, a morte -, a miséria humana é o sinal manifesto da condição nativa de fraqueza na qual o homem se encontra após o primeiro pecado e da necessidade de uma salvação. É por isso que ela atrai a compaixão de Cristo Salvador, que

19 CNBB. Comunidades Eclesiais de Base na Igreja do Brasil. 6. ed. São Paulo: Paulinas, 1999. p. 5-9.

20 CASALDÁligA, Pedro. Na procura do Reino: Antologia de textos 1968/1988. São Paulo: FTD, 1988. p. 219-220. 
quis assumi-la identificando-se com os "mais pequeninos entre os seus irmãos" (Mt 25,40.45). É também por isso que todos aqueles que ela atinge são objetos de um amor preferencial por parte da Igreja que, desde as suas origens, apesar das falhas de muitos de seus membros, não deixou nunca de se esforçar por aliviá-los, defendê-los e libertá-los. Amando os pobres, enfim, a Igreja testemunha a dignidade do homem. Ela afirma claramente que este vale mais pelo que é do que pelo que possui. Ela testemunha que essa dignidade não pode ser destruída, seja qual for a situação de miséria, de desprezo, de rejeição e de impotência a que o homem foi reduzido. Ela mostra-se solidária com aqueles que não contam para uma sociedade da qual se veem espiritual e às vezes até mesmo fisicamente rejeitados. ${ }^{21}$

Dizem que ela está morta, que é heresia, que seus teólogos e teólogas estão excomungados, que faz um grande mal para a Igreja... tudo inverdade, tudo fake news; porém, enquanto existir injustiça e houverem os pobres e se acreditar em Deus como libertador, a TdL estará presente e atuante.

Há um desafio: fazer descer da cruz os povos crucificados!

Ela é uma árvore que dá frutos bons, está mais viva do que nunca!

\section{Conclusão}

Desde suas origens na década de 1960, a TdL tem se transformado, tem produzido, tem se reinventado, tem se refundado e apontando o caminho que leva ao seguimento a Jesus de Nazaré. 50 anos depois, há uma nova nomenclatura nos meios acadêmicos e populares: Teologias da Libertação.

Marcelo Barros explica:

Tenho consciência de que falar em uma proposta de Teologias da libertação para os nossos dias é muito ambicioso e arriscado. Devemos falar no plural de teologias da libertação (elaboradas sempre a partir de experiências comunitárias e coletivas populares, mesmo se condensadas e expressas por um único autor ou autora) e teologias sobre a libertação, produzidas de forma mais sistemática e acadêmica, com orientação aberta e na perspectiva transformadora e a partir da opção

21 CONGREGAÇÃO PARA A DOUTRINA DA FÉ. Instrução sobre a Liberdade Cristã e a Libertação. São Paulo: Paulinas, 1986. p. 50-51. 
pelos pobres. Do mesmo modo, ao falar "nestes dias", assumamos que o projeto é restrito e sempre incompleto. Deve se atualizar e se renovar progressivamente, cada vez, na escuta do que o Espírito diz, a cada dia, às Igrejas e a nós. ${ }^{22}$

A Igreja dos Pobres é um projeto de vida útil e necessário, que deve ser abraçado por muitas pessoas; da mesma forma a Teologia da Libertação, mais do que nunca, ela se faz presente na história do Brasil, da América Latina e Caribe e de todo o mundo; está bem viva, e dando sinais claros que não irá desaparecer tão cedo, apesar das perseguições e mentiras ditas em muitos lugares, por pessoas que ainda não conseguem entendê-la, não conseguem perceber o contexto que a levou a ser uma teologia mais pé no chão, mais próxima da realidade do povo.

É preciso mergulhar mais fundo na vida dos pobres, sentir na pele o que sentem hoje. Veremos que o sonho de São João XXIII e do Papa Francisco por uma Igreja dos Pobres não é loucura, mas necessidade, exigência evangélica.

É a exigência evangélica que faz com que a TdL esteja sempre presente em nosso meio. É por causa da defesa da vida que teólogos e teólogas da libertação, da primeira e da nova geração, começam, em pequenos passos, o enfrentamento contra as ações de políticas governamentais que favorecem à morte ao invés da vida.

Nesse contexto de enfrentamento, por respeito à vida, aguardamos a vacinação em toda a população brasileira para que o retorno às ruas possa acontecer com muita segurança. $\mathrm{O}$ isolamento social nesta pandemia da COVID-19 tem sido benéfico pois exige de mim, de cada um, de cada uma de nós, conhecer alguém que pouco conhecemos: nós mesmos! Nestes dias de quarentena, e acontece com todo mundo que se deixa tocar por esta experiência: é preciso encarar a mim mesmo sem máscaras, sem subterfúgios, sem rotas de escape, apenas eu comigo mesmo, para entender que no fundo: Espiritualidade é viver pelo Espírito!

Se eu vivo no Espírito, e experimento uma espiritualidade libertadora, ela me impulsiona a ser um teólogo da libertação, não posso voltar a ser quem eu era antes da pandemia. Preciso ir além, exercitando a cada dia a misericórdia, a compaixão, a justiça, a paz. Precisamos voltar à anormalidade, pois a normalidade não deu certo!

22 BARROS, 2019, p. 14. 
A Espiritualidade da Libertação é aquela que está diretamente relacionada com a libertação integral do ser humano e que lança suas redes em águas mais profundas quando se trata de defender a vida nova e soberana para todos e todas. É uma espiritualidade de resistência e enfrentamento num mundo de exclusões, violências e extermínios.

Juan José Tamayo afirma:

Não existe teologia sem espiritualidade. Ambas estão profundamente interligadas. A espiritualidade é uma dimensão fundamental do ser humano. É inerente a ele como sua corporeidade, sua sociabilidade, sua praticidade, subjetividade e historicidade. Pertence, portanto, ao seu substrato mais profundo. O ser humano não pode renunciar a isso. Uma espiritualidade desligada do corpo leva ao espiritualismo; separado da razão, termina em sentimentalismo; desvinculado das práxis, acaba sendo passivo; desenraizado da história, é uma fuga da realidade; sem subjetividade, é impessoal; sem sociabilidade, termina em solipsismo.

Mas nem pode a espiritualidade ser mecanicamente reduzida ou deduzida das condições materiais de existência. Tem autonomia, certamente, mas é relativa, pois se baseia nas condições em que vivem os seres humanos: políticas, sociais, econômicas, culturais e biológicas, ao mesmo tempo que os ilumina e os transforma.

A espiritualidade é também a dimensão central da teologia da libertação, que, no entanto, muitas vezes é acusada de ser muito politizada, de ter apenas um projeto terreno e de colocar a transcendência entre parênteses.

A espiritualidade não é uma dimensão independente da libertação, assim como o espírito não está, nem deveria estar separado da totalidade do ser humano. Espiritualidade e libertação se complementam e se enriquecem. ${ }^{23}$

A Teologia da Libertação é antes de tudo, uma libertação da teologia! E por levar a sério a libertação é que se entende por uma teologia descolonizadora, desde a opção pelos pobres oprimidos, com o reconhecimento das diversidades culturais e em atitude crítica do capitalismo.

Concluo, que nossa atenção, nosso olhar, a partir da Teologia da Libertação, se volta para o diálogo, o respeito e o encontro com novas

23 TAMAYO, Juan José. Otra Teología es posible: Pluralismo religioso, interculturalidad y feminismo. España: Herder Editorial, 2011. p. 289-291. 
realidades e saberes. Neste processo de descolonização e libertação da teologia, a Teologia da Libertação é refundada, e nas próximas décadas, continuará dando frutos bons para a Igreja na América Latina e Caribe. Nessa travessia, seguindo Jesus de Nazaré e divulgando a TdL, digo, parafraseando uma frase hodierna de Leonardo Boff: "O que a teologia da libertação sempre buscou foi reforçar uma Igreja toda ela servidora e pobre, comprometida na luta contra a fome e a exclusão das grandes maiorias da humanidade". ${ }^{24}$

\section{Referências}

ALVES, Rubem. Teologia da Libertação, Igreja Presbiteriana e Ditadura Militar. Disponível em: https://www.youtube.com/ watch?v=njJW1xAMW3Y. Acesso em: 3 jun. 2021.

AQUINO JÚNIOR, Francisco de. Teologia em saída para as periferias. São Paulo: Paulinas; Recife: UNICAP, 2019.

BARROS, Marcelo. Teologias da Libertação para os nossos dias. Petrópolis: Editora Vozes, 2019.

BOFF, Leonardo. Igreja: Carisma e Poder - edição revista. 2. ed. Rio de Janeiro: Record, 2010.

BOFF, Leonardo. Jesus Cristo Libertador. 20. ed. Petrópolis: Editora Vozes, 2009.

BOFF, Leonardo. Teologia da Libertação. In: DICIONÁRIO DO CONCÍLIO VATICANO II. São Paulo: Paulinas; Paulus, 2015.

CASALDÁligA, Pedro. Na procura do Reino: Antologia de textos 1968/1988. São Paulo: FTD, 1988.

CNBB. Comunidades Eclesiais de Base na Igreja do Brasil. 6. ed. São Paulo: Paulinas, 1999.

CODINA, Victor. Nuevos desafios de la Teología de la Liberación. Perspectiva Teológica, Belo Horizonte, v. 48, n. 2, maio/ago. 2016, p. 229-243.

CONGREGAÇÃO PARA A DOUTRINA DA FÉ. Instrução sobre a Liberdade Cristã e a Libertação. São Paulo: Paulinas, 1986.

24 Cf. BOFF, Leonardo. Igreja: Carisma e Poder. Edição revista. 2. ed. Rio de Janeiro: Record, 2010. p. 18. 
FRANCISCO. Exortação Apostólica Evangelii Gaudium - A Alegria do Evangelho: ao Episcopado, ao clero, às pessoas consagradas e aos fiéis leigos sobre o anúncio do Evangelho no mundo atual. São Paulo: Paulinas, 2013.

FRANCISCO. Mensagem do Papa Francisco para o V Dia Mundial dos Pobres. Disponível em: https://www.vaticannews.va/pt/papa/news/202106/mensagem-do-santo-padre-para-o-vdia-mundial-dos-pobres.html. Acesso em: 17 jun. 2021.

GUTIÉRREZ, Gustavo. Teologia da Libertação: Perspectivas. São Paulo: Edições Loyola, 2000.

JOÃO PAULO II. Mensagem do Santo Padre ao Episcopado do Brasil - Roma, 9 de abril de 1986. São Paulo: Edições Loyola, 1986.

MÜLLER, Gerhard Ludwig. Pobre para os pobres: A missão da Igreja. São Paulo: Paulinas, 2014.

MÜLLER, Gerhard Ludwig. GUTIÉRREZ, Gustavo. Ao lado dos pobres: Teologia da Libertação. São Paulo: Paulinas, 2014.

TAMAYO, Juan José. Otra Teología es posible: Pluralismo religioso, interculturalidad y feminismo. España: Herder Editorial, 2011.

TRADUÇÃO ECUMÊNICA DA BÍBLIA - TEB. 3. ed. São Paulo: Edições Loyola, 2020. 